\title{
Binding of antibodies in sera from Type 1 (insulin-dependent) diabetic patients to glutamate decarboxylase from rat tissues. Evidence for antigenic and non-antigenic forms of the enzyme
}

\author{
M. R. Christie, T.J.Brown and D.Cassidy \\ Nuffield Department of Clinical Biochemistry, John Radcliffe Hospital, Headington, Oxford, UK
}

\begin{abstract}
Summary. An islet protein of $\mathrm{M}_{\mathrm{r}} 64000$, identified as the $\gamma$-amino butyric acid (GABA)-synthesizing enzyme, glutamate decarboxylase, is a major target for antibodies in Type 1 (insulin-dependent) diabetes mellitus. This enzyme is also expressed in brain and in some other tissues and may exist in multiple forms. The aim of this study was to determine the ability of antibodies from diabetic patients to recognize glutamate decarboxylase from rat islets, brain and other normal rat tissues. Glutamate decarboxylase was detected at high activity levels in brain and at lower levels in islets, kidney, liver, pituitary gland, thyroid gland, adrenal gland, testis and ovary. The ability of antibodies in sera of diabetic patients to immunoprecipitate enzyme activity from detergent extracts of tissues was determined. Antibodies in sera from diabetic pa-
\end{abstract}

tients were found to bind the enzyme from islet and brain extracts, but bound less than $20 \%$ of the activity from other tissues. The ability of antibodies to immunoprecipitate the brain enzyme was significantly correlated with the presence of antibodies to the islet 64 kilodalton antigen. These studies show that the glutamate decarboxylase activity expressed in brain shares antigenic determinants with the islet 64 kilodalton antigen. Isoforms of the enzyme expressed in other nonneuronal tissues may be antigenically distinct and may lack determinants recognized by diabetes-associated antibodies.

Key words: Autoantigens, autoantibodies, glutamic acid decarboxylase, pancreatic islets.
Type 1 (insulin-dependent) diabetes mellitus is the result of the specific destruction of the Beta cells of the pancreatic islet. There is considerable evidence to suggest that the disease is autoimmune in nature [1], and this has lead to the search for Beta-cell specific components that may be the targets of an autoimmune response. An islet protein of $\mathrm{M}_{\mathrm{r}} 64000$ (64 kilodalton ( $\mathrm{kDa}$ ) antigen) has been described as a major islet cell protein recognized by antibodies in sera of newly-diagnosed Type 1 diabetic patients $[2,3]$. This protein was shown to be expressed by Beta cells of the pancreatic islet but was not detected in other cells within the islet or in several other tissues [4]. By analysing antibody reactivity to proteolytic fragments of the antigen, two distinct antibody specificities have been identified in sera of Type 1 diabetic patients that recognize $50 \mathrm{kDa}$, or both $37 \mathrm{kDa}$ and $40 \mathrm{kDa}$ fragments of the antigen [5]. More than $90 \%$ of recent-onset diabetic patients possess antibodies to at least one of the $64 \mathrm{kDa}$ antigen-derived tryptic fragments, suggesting that the presence of these antibodies may be highly sensitive markers for disease development [5].

The $64 \mathrm{kDa}$ antigen was identified recently as glutamate decarboxylase (GAD) [6]. GAD is the enzyme responsible for the synthesis of the neurotransmitter, $\gamma$-amino butyric acid (GABA) in the GABA-ergic neurons of the central nervous system. Within the pancreatic islet, GAD and GABA expression have been shown to be restricted to the Beta cells [6-8]. GABA synthesis and secretion in islets may play a role in the paracrine regulation of glucagon or somatostatin secretion [9].

In addition to the central nervous system and pancreatic Beta cells, GABA and GAD have also been detected in several other tissues including kidney, liver, adrenal gland, ovary and testis [10-13]. In our previous analysis of tissue specificity, we failed to detect expression of $64 \mathrm{kDa}$ antigen in several of these tissues. This could, potentially, be the result of the low level of expression of the enzyme in these tissues. However, there is evidence that GAD exists as multiple isoforms. Two forms of GAD (GAD 65 and $\mathrm{GAD}_{67}$ ) have been identified in mammalian brain which differ in their antigenic properties and intraneuronal distribution [14]. Furthermore, three kinetically distinct forms of GAD have been purified from brain on the basis of hydrophobic-interaction chromatography [15]. Both $\mathrm{GAD}_{65}$ and $\mathrm{GAD}_{67}$ have been detected in pancreatic islets and both forms are recognized by diabetes-associ- 
Table 1. Glutamate decarboxylase activity of rat tissues

\begin{tabular}{lc}
\hline Tissue & $\begin{array}{c}\text { Glutamate decarboxylase activity } \\
\left(\mu \mathrm{mol} \cdot 16 \mathrm{~h}^{-1} \cdot \mathrm{g}^{\mathrm{g} \text { protein }}{ }^{-1}\right)\end{array}$ \\
\hline Brain & $104.26 \pm 1.51$ \\
Islets & $9.52 \pm 0.16$ \\
Kidney & $6.55 \pm 0.26$ \\
Liver & $3.73 \pm 0.34$ \\
Pituitary gland & $3.58 \pm 1.80$ \\
Thyroid gland & $2.75 \pm 0.35$ \\
Adrenal gland & $1.89 \pm 0.77$ \\
Testis & $1.46 \pm 0.12$ \\
Ovary & $0.92 \pm 0.09$ \\
Spleen & $<0.5$ \\
Thymus & $<0.5$ \\
\hline
\end{tabular}

The activity of glutamate decarboxylase in tissue homogenates was determined by measuring the enzyme-catalysed release of ${ }^{14} \mathrm{CO}_{2}$ from $\left[1-{ }^{14} \mathrm{C}\right]$ glutamic acid. Results are expressed as the means \pm SEM of three independent observations

ated antibodies $[16,17]$. However, the identities of isoforms of GAD expressed by other non-neuronal tissues have yet to be resolved and it is possible that isoforms of GAD expressed by some tissues may lack antigenic determinants recognized by the diabetes-associated antibodies. The aim of the present study was to determine the ability of antibodies in sera of Type 1 diabetic patients to bind GAD from different normal rat tissues.

\section{Subjects, materials and methods}

\section{Subjects}

Antibodies to GAD were analysed in sera from diabetic and nondiabetic individuals. Sera from 25 Type 1 diabetic children (aged 6-17 years), obtained within 10 days of diagnosis and previously characterized for antibodies to the $64 \mathrm{kDa}$ antigen [18] and tryptic fragments of the antigen [5] were provided by Dr. D. Daneman (The Hospital for Sick Children, Toronto, Ontario, Canada). Sera from 30 healthy individuals (aged $21-70$ years) with no known family history of diabetes were included as control subjects. Serum from a diabetic patient previously used as a reference standard in $64 \mathrm{k}$ antibody assays $[3,5,18]$ was included as a positive control in GAD-antibody determinations.

\section{Assay for glutamate decarboxylase in tissue extracts}

Whole organs (brain, kidney, liver, pituitary gland, thyroid gland, adrenal gland, testis, ovary, spleen and thymus) were dissected from adult male or female Wistar rats. Pancreatic islets were isolated from pancreases of neonatal Wistar rats by collagenase digestion and Percoll density gradient centrifugation as previously described [19]. Tissues were homogenized with a Teflon-glass homogenizer in five times their weight of $1 \mathrm{mmol} / \mathrm{l}$ 2-aminoethyl isothiouronium bromide, $0.2 \mathrm{mmol} / 1$ pyridoxyl phosphate, $1 \mathrm{mmol} / 1$ EDTA, $1 \mathrm{mmol} / \mathrm{l}$ benzamidine, $25 \mathrm{mmol} / 1$ potassium phosphate, $\mathrm{pH} 7.0$ (homogenization buffer). For the assay of GAD, aliquots of homogenates $(2-25 \mu \mathrm{l})$ were incubated for $16 \mathrm{~h}$ at $37^{\circ} \mathrm{C}$ with $25 \mu \mathrm{l}$ of $5 \mathrm{mmol} / \mathrm{l} \mathrm{L-glutamic} \mathrm{acid} \mathrm{and} 0.125 \mu \mathrm{Ci}\left[1{ }^{14} \mathrm{C}\right] \mathrm{L}$-glutamic acid in homogenization buffer. ${ }^{14} \mathrm{CO}_{2}$ released during the reaction was absorbed onto filter papers soaked with $50 \mu \mathrm{l}$ of $1 \mathrm{~mol} / 1$ hyamine hydroxide in methanol and quantified by liquid scintillation spectrometry.

\section{Immunoprecipitation of glutamate decarboxylase from tissue extracts by sera}

The detergent, Nonidet $\mathrm{P} 40$, was added to homogenates of tissues to a final concentration of $1 \%$ (weight/volume, w/v) and extracted for $2 \mathrm{~h}$ on ice. The soluble tissue extract was separated from insoluble material by centrifugation at $100,000 \mathrm{~g}$ for $30 \mathrm{~min}$. Tissue extracts were diluted to a GAD activity of $4 \times 10^{-8} \mathrm{~mol} \cdot \mathrm{ml}^{-1} \cdot 16 \mathrm{~h}^{-1}$ in homogenization buffer containing $1 \%$ Nonidet $\mathrm{P} 40$ and $50 \mu \mathrm{l}$ aliquots of the extract incubated with $12.5 \mu \mathrm{l}$ of test serum for $5 \mathrm{~h}$ on ice. Immune complexes were isolated on $25 \mu \mathrm{I}$ of protein A Sepharose

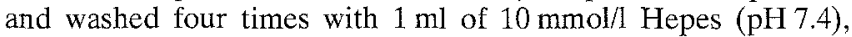
$155 \mathrm{mmol} / \mathrm{l} \mathrm{NaCl}, 10 \mathrm{mmol} / \mathrm{l}$ benzamidine, $0.5 \%(\mathrm{w} / \mathrm{v}$ ) Triton $\mathrm{X}-114$, $0.5 \mathrm{mg} / \mathrm{ml}$ bovine serum albumin, $1 \mathrm{mmol} / \mathrm{l} 2$-aminoethylisothiouronium bromide, $0.2 \mathrm{mmol} / 1$ pyridoxyl phosphate and once in $1 \mathrm{ml}$ of homogenization buffer. GAD activity associated with immunoprecipitates was assayed as described above.

The activity of antibodies to brain GAD in sera from control and diabetic sera were quantified by determining the enzyme activity immunoprecipitated by sera from a cytosolic extract of rat brain. Brains were homogenized in a 10 -fold volume of homogenization buffer and centifuged at $100,000 \mathrm{~g}$ for $30 \mathrm{~min}$. The supernatant was diluted to a GAD activity of $4 \times 10^{-8} \mathrm{~mol} \cdot \mathrm{ml}^{-1} \cdot 16 \mathrm{~h}^{-1}$ in homogenization buffer and immunoprecipitated with sera as described above. Enzyme activity in immunoprecipitates was calculated relative to that immunoprecipitated by a standard antibody-positive reference serum included in each assay. Test sera were regarded as positive if the relative antibody activity exceeded $2 \mathrm{SD}$ of the activity in sera from a group of control individuals.

\section{Assay for antibodies to the islet $64 \mathrm{kDa}$ antigen}

The serum activity of antibodies to the $64 \mathrm{kD}$ a antigen in detergentsolubilized extracts of islets (64k-antibodies), and antibodies to $50 \mathrm{kDa}, 40 \mathrm{kDa}$ and $37 \mathrm{kDa}$ polypeptides in trypsin-solubilized extracts of islets ( $50 \mathrm{k}-, 40 \mathrm{k}$ - and $37 \mathrm{k}$-antibodies, respectively), were determined as previously described [5].

\section{Protein determinations}

The protein content of tissues was assayed by the Biuret Reaction [20].

\section{Statistical analysis}

The degree of association between antibody activities was tested by linear regression analysis.

\section{Results}

\section{Activity of glutamate decarboxylase in tissue extracts}

The results of an analysis of GAD activity in tissue homogenates of normal adult rat tissues are presented in Table 1 . The highest GAD activity was found in brain. Enzyme activity was also detected in islets, kidney, liver, pituitary gland, thyroid gland, adrenal gland, testis, and ovary. GAD activity of spleen and thymus was below the detection limit of the assay.

\section{Immunoprecipitation of glutamate decarboxylase by antibodies in sera of diabetic patients}

In all tissues, GAD was detected in particulate and cytosolic forms. In order to investigate whether GAD in each tissue was recognized by antibodies in diabetic patients' 


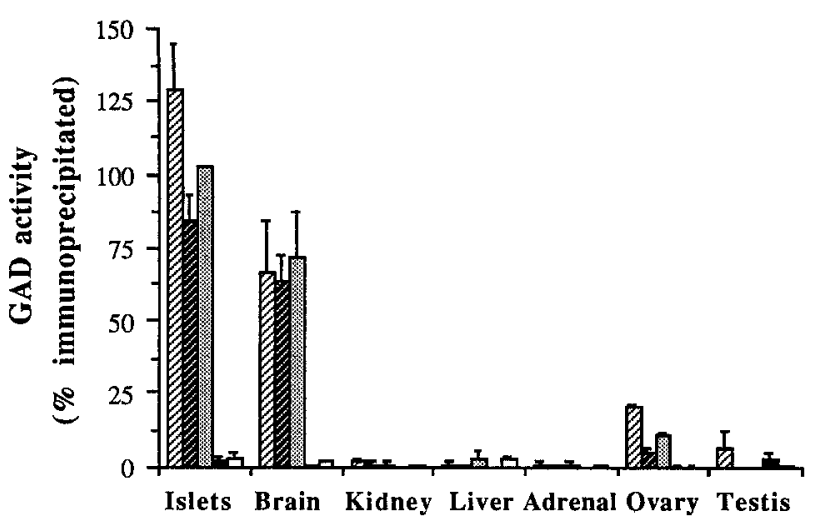

Fig. 1. Recognition of glutamate decarboxylase (GAD) by antibodies in sera from Type 1 (insulin-dependent) diabetic or control individuals. Nonidet P40-solubilized extracts of rat tissues were adjusted to the same GAD activity and incubated with sera from $64 \mathrm{k}$ antibody-positive diabetic patients (first three bars for each tissue), with serum from a $64 \mathrm{k}$-antibody-negative diabetic patient (fourth bar) or a 64k-antibody-negative control serum (fifth bar). The activity of GAD immunoprecipitated was calculated as a proportion of the total activity added. The results are the means \pm SEM of $2-4$ independent observations

sera, tissue homogenates were extracted in Nonidet P40 to solubilize the membrane-associated enzyme. The activities recovered from pituitary gland, thyroid gland, spleen and thymus were too low for these tissues to be included in further analyses. Detergent extraction solubilized greater than $85 \%$ of the total GAD activity from other tissues without inhibiting enzyme activity. Detergent extracts from these tissues were adjusted to an equivalent GAD activity and incubated with sera previously determined to be either strongly positive or negative for antibodies to the islet $64 \mathrm{kDa}$ antigen. Immune complexes were adsorbed onto protein A Sepharose and the activity of GAD associated with immunoprecipitates determined. The 64k-antibody-positive sera immunoprecipitated greater than $63 \%$ of the GAD activity from islets or brain, but bound less than $20 \%$ of the activity from all other tissues (Fig. 1).

Experiments were performed to determine whether there is a direct association between antibodies to brain GAD and antibodies to the islet $64 \mathrm{kDa}$ antigen. Sera from 25 recent-onset diabetic children, previously characterized for antibodies to the $64 \mathrm{kDa}$ antigen [5, 18], and 30 healthy control individuals, were analysed for antibodies to the rat brain enzyme. The mean GAD activity ( \pm SD) immunoprecipitated by antibodies in sera of the 30 control sera was $6.17 \pm 3.44 \%$ of that precipitated by a reference serum included in each assay. Sera were regarded as positive if the GAD activity in immunoprecipitates exceeded $2 \mathrm{SD}$ of the mean activity of the control subjects' sera. Sixteen of the diabetic patients (64\%) were determined to be positive for antibodies to brain GAD. Antibodies to intact islet $64 \mathrm{kDa}$ antigen and antibodies to $50 \mathrm{kDa}, 40 \mathrm{kDa}$ and $37 \mathrm{kDa}$ tryptic fragments of $64 \mathrm{kDa}$ antigen were present in $20(80 \%), 20(80 \%), 19(78 \%)$, and $19(78 \%)$ of the 25 diabetic patients respectively. A strong positive correlation was found between antibodies to brain GAD and islet $64 \mathrm{kDa}$ antigen (Fig. $2 \mathrm{a} ; r=0.91$, $p<0.001$ ). A weaker, but significant, correlation was observed between GAD-antibodies and antibodies to the $50 \mathrm{kDa}$ tryptic fragment (Fig. $2 \mathrm{~b} ; r=0.70, p<0.001$ ). GAD-antibodies were not associated with antibodies to the $37 \mathrm{kDa}$ or $40 \mathrm{kDa}$ tryptic fragments (Fig. $2 \mathrm{c}$ and d).

\section{Discussion}

Baekkeskov et al. [6] have provided evidence that at least part of the diabetes-associated islet $64 \mathrm{kDa}$ antigen is the GABA-synthesizing enzyme, glutamate decarboxylase. In particular, antibodies in sera of Type 1 diabetic patients were found to immunoprecipitate a GAD activity from brain and islet extracts. The authors did not demonstrate a direct association between antibodies to GAD and antibodies to the islet $64 \mathrm{kDa}$ protein. In the results presented here, a strong positive correlation between antibodies to brain GAD and 64k-antibodies was observed, providing convincing evidence that the islet antigen shares antigenic properties with brain $\mathrm{GAD}$. Fewer sera from recent-onset diabetic patients were positive in the GAD-antibody assay (64\%) than were positive for $64 \mathrm{k}$-antibodies ( $80 \%$ ). It is possible that inhibitory effects of antibody binding on enzyme activity may reduce the number of individuals positive for GAD-antibodies in this assay. All 64k-antibody-positive patients who were negative for GAD-antibodies had low $64 \mathrm{k}$-antibody levels. Thus, under the conditions described, the GAD-antibody assay has a lower sensitivity of antibody detection than the 64k-antibody assay. However, the relative simplicity of the GAD-antibody assay procedure, particularly in the preparation of the antigen extract, makes this assay more attractive for the further analysis of antibodies to the antigen in specific populations.

Both brain GAD and the islet $64 \mathrm{kDa}$ antigen migrate as two components on sodium dodecyl sulphate-polyacrylamide gel electrophoresis [6] and may therefore be complexes of more than one polypeptide chain. There is evidence that individual components of brain GAD may differ immunochemically [21]. By analysing antibodies to tryptic fragments of the $64 \mathrm{kDa}$ antigen, we have identified two distinct antibody specificities in sera of Type 1 diabetic patients [5]. Determinants recognized by these antibodies may be localized on different polypeptide chains [5]. A significant association between antibodies to brain GAD and antibodies to a $50 \mathrm{kDa}$ trypsin fragment was observed in this study, suggesting that determinants recognized by GAD-antibodies are present on this fragment. The degree of association was weaker than the association with antibodies to intact antigen. Trypsin treatment may alter the conformation of some determinants on the native antigen, impeding or enhancing recognition by autoantibodies. No association was observed between GAD-antibodies and antibodies to either the $37 \mathrm{kDa}$ or $40 \mathrm{kDa}$ tryptic fragments. Some sera which did not immunoprecipitate a GAD activity were strongly positive for antibodies to these fragments. We have previously suggested that antibodies to the $37 \mathrm{kDa}$ and $40 \mathrm{kDa}$ polypeptides recognize determinants that are hidden on the native $64 \mathrm{kDa}$ antigen, but that are exposed on 
a

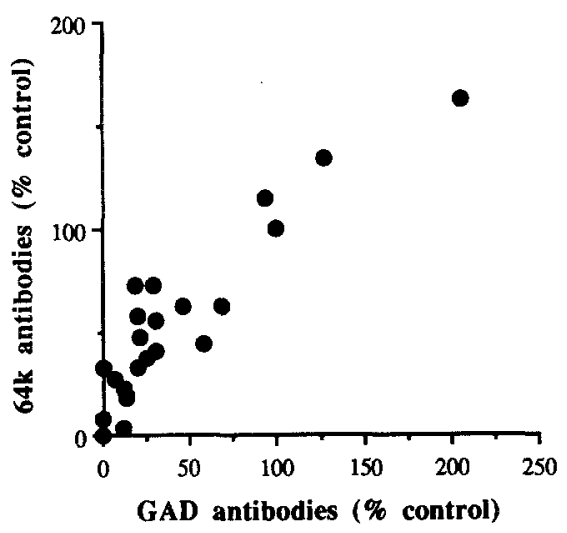

c

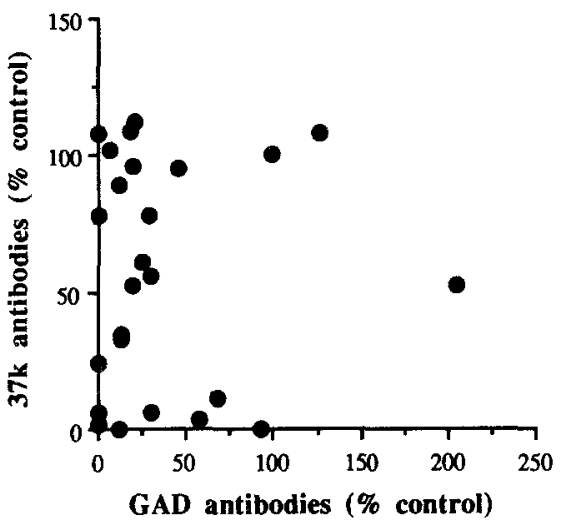

b

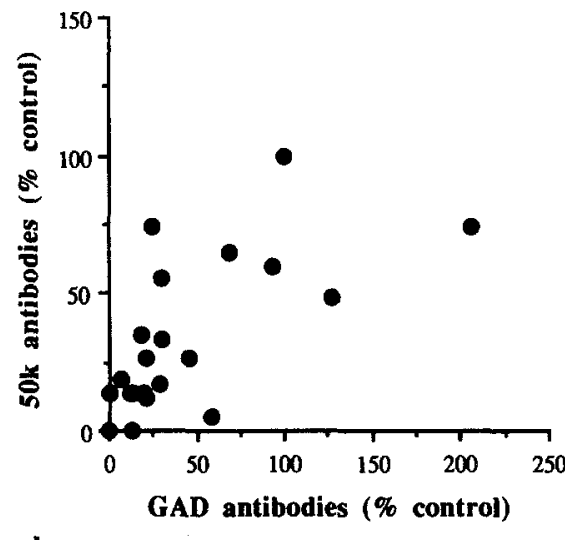

d

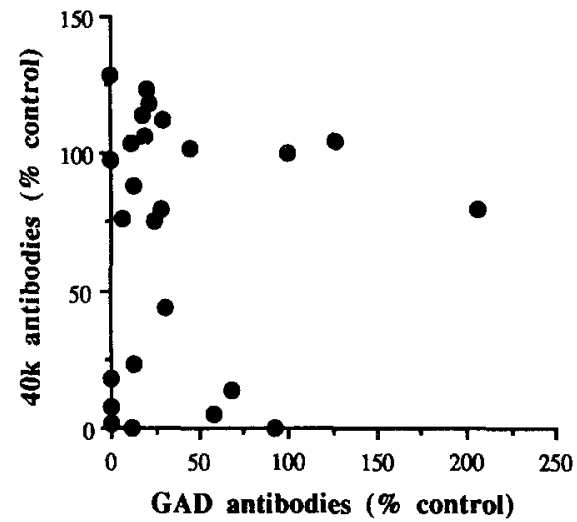

Fig. 2. Associations of antibodies to rat brain glutamate decarboxylase (GAD) with antibodies to islet $64 \mathrm{kDa}$ antigen. The ability of antibodies in sera from Type 1 (insulin-dependent) diabetic patients to immunoprecipitate GAD from brain extracts was compared with the ability of antibodies to immunoprecipitate $64 \mathrm{kDa}$ antigen from detergent extracts of islets (a), or $50 \mathrm{kDa}(\mathbf{b})$, $37 \mathrm{kDa}(\mathbf{c})$ and $40 \mathrm{kDa}(\mathbf{d})$ fragments of antigen from trypsin-treated particulate fractions of islets. Data are expressed as a percentage of the antibody in a $64 \mathrm{k}$-antibody-positive reference serum and are the means of the least two independent observations trypsin cleavage [5]. The failure of $37 \mathrm{k}$ - and $40 \mathrm{k}$-antibodies to bind a GAD activity in non-protease-treated brain extracts is consistent with this proposal. However, it is also possible that these antibodies bind a protein that is distinct from the GAD enzyme.

In addition to pancreatic Beta cells, GAD has been detected in a number of other non-neuronal tissues, either by measurement of enzyme activity or by immunocytochemistry with antibodies raised to the brain enzyme [10-13]. Consistent with these reports, we were able to detect GAD activity in kidney, liver, pituitary gland, adrenal gland, thyroid gland, testis and ovary. However, in contrast to the enzyme in islets and brain, GAD extracted from most of these tissues was not recognized by antibodies in sera of $64 \mathrm{k}$-antibody-positive diabetic patients. In an earlier study, diabetes-associated antibodies failed to immunoprecipitate a $64 \mathrm{kDa}$ protein from a number of non-islet tissues, including kidney, liver, adrenal and pituitary glands [4]. The GAD activity expressed by these tissues appears to be immunochemically distinct from the enzyme in brain and islets, lacking antigenic determinants recognized by diabetes-associated $64 \mathrm{k}$-antibodies. Despite failure of autoantibodies to bind GAD from several non-neuronal tissues, GAD expressed by these tissues may have structural features in common with the brain enzyme. Polyclonal antibodies raised to the brain enzyme recognize a GAD immunoreactivity on sections of both ovary and testis $[12,13]$. Furthermore, cDNA for brain
$\mathrm{GAD}_{67}$ has been shown to hybridize with mRNA isolated from testis [13]. The major testicular mRNA species recognized was 2.5 kilobases, distinct from the 3.7 kilobase mRNA predominant in brain. These results indicate that GAD in brain and testis are encoded by different mRNA species, but that these molecules have considerable sequence homology and the proteins may share some antigenic determinants recognized by GAD antisera. Recent studies have shown that $\mathrm{cDNA}$ for $\mathrm{GAD}_{65}$, which hybridizes predominantly with a 5.6 kilobase mRNA in islets and brain, also recognizes a 2.5 kilobase transcript in human islets, which may be related to the major testicular species [22]. Comparison of nucleotide sequences of cDNA for antigenic and non-antigenic forms of the GAD molecule may help to identify domains recognized by autoantibodies in diabetes.

It is unclear whether the distinct GAD activities expressed in different tissues have similar functions. It is evident that GABA synthesis in brain has a signalling role, GABA being the major inhibitory neurotransmitter in the nervous system [23]. There is evidence that GABA has a signalling function in islets as well. In pancreatic Beta cells, GABA and GAD co-localize with microvesicles that have similar properties to the GABA storage vesicles in the nervous system [24]. Furthermore, GABA receptors are expressed by pancreatic Alpha cells, and GABA, or GABA agonists, have been shown to influence the secretion of glucagon and somatostatin release from 
pancreatic islets $[9,25]$. GABA may therefore be a paracrine regulator of hormone release in the islet. In other tissues, a signalling function for GABA is less clear. In kidney, GAD may have a metabolic role, particularly in the catabolism of glutamine [10]. In spermatozoa, GAD-like immunoreactivity was detected predominantly in the midpiece region, which is rich in mitochondria and responsible for energy generation, again suggestive of a metabolic function. Thus, GAD enzymes expressed in kidney, testis and possibly other tissues may be functionally, as well as antigenically distinct from the enzymes expressed in brain and islets.

In conclusion, the results of this study show that, despite the rather widespread tissue distribution of GAD enzyme activity, GAD isoforms recognized by autoantibodies in diabetes may be restricted to the brain, an immunologically privileged site, and pancreatic Beta cells. Further characterization of the structures and patterns of expression of the GAD isoforms may help determine why some forms of GAD are autoantigens in diabetes whereas others are not.

Acknowledgements. We thank Mr. M. A.Payton for technical assistance. This study was supported by the Juvenile Diabetes Foundation, Novo/Nordisk and the Royal Society. MRC is a Royal Society University Research Fellow and TJB is supported by a Medical Research Council Research Studentship.

\section{References}

1. Eisenbarth GS (1986) Type 1 diabetes. A chronic autoimmune disease. N Engl J Med 314: 1360-1368

2. Baekkeskov S, Nielsen JH, Marner B, Bilde T, Ludvigsson J, Lernmark $\AA$ (1982) Autoantibodies in newly diagnosed diabetic children immunoprecipitate human pancreatic islet cell proteins. Nature (Lond) 298: 167-169

3. Christie M, Landin-Olsson M, Sundkvist G, Dahlquist G, Lernmark $\AA$, Baekkeskov $S$ (1988) Antibodies to a $M_{r}-64000$ islet cell protein in Swedish children with newly-diagnosed Type 1 (insulin-dependent) diabetes. Diabetologia 31: 597-602

4. Christie MR, Pipeleers DG, Lernmark Å, Baekkeskov S (1990) Cellular and subcellular localization of a Mr-64000 protein autoantigen in insulin-dependent diabetes. J Biol Chem 265: 376-381

5. Christie MR, Vohra G, Champagne P, Daneman D, Delovitch TL (1990) Distinct antibody specificities to a $64-\mathrm{kD}$ islet cell antigen in Type 1 diabetes as revealed by trypsin treatment. $\mathbf{J}$ Exp Med 172: 789-794

6. Baekkeskov S, Aanstoot HK, Christgau Set al. (1990) Identification of the $64 \mathrm{k}$ antigen in insulin-dependent diabetes as the GABA-synthesizing enzyme glutamic acid decarboxylase. Nature (Lond) 347: 151-156

7. Okada $Y$, Taniguchi $H$, Shimada $C$ (1976) High concentration of GABA and high glutamate decarboxylase activity in rat pancreatic islets and human insulinoma. Science 194:620-622

8. Garry DJ, Sorenson RL, Elde RP, Maley BE, Madsen A (1986) Immunohistochemical colocalization of GABA and insulin in $\beta$-cells of rat islet. Diabetes 35: 1090-1095

9. Rorsman P, Berggren P-O, Bokvist K et al. (1989) Glucose inhibition of glucagon secretion involves activation of GABA-Areceptor chloride channels. Nature (Lond) 341: 233-236

10. Whelan DT, Scriver CR, Mohyuddin F (1969) Glutamic acid decarboxylase and gamma-aminobutyric acid in mammalian kidney. Nature (Lond) 224: 916-917
11. Erdö SL, Kiss B (1986) Presence of GABA, glutamate decarboxylase and GABA transaminase in peripheral tissues: a collection of quantitative data. In: Erdö SL, Bowery NG (eds) GABAergic mechanisms in the mammalian periphery. Raven Press, New York, pp 35-56

12. Erdö SL, Joo F, Wolff JR (1989) Immunohistochemical localization of glutamate decarboxylase in the rat oviduct and ovary: further evidence for non-neural GABA systems. Cell Tissue Res 255: 431-434

13. Persson H, Pelto-Huikko M, Metsis Met al. (1990) Expression of the neurotransmitter-synthesizing enzyme glutamic acid decarboxylase in male germ cells. Mol Cell Biol 10: 4701-4711

14. Kaufman DL, Houser CR, Tobin AJ (1991) Two forms of the $\gamma$-aminobutyric acid synthetic enzyme glutamate decarboxylase have distinct intraneuronal distributions and cofactor interactions. J Neurochem 56: 720-723

15. Spink DC, Porter TG, Wu S, Martin DL (1985) Characterization of three kinetically distinct forms of glutamate decarboxylase from pig brain. Biochem J 231: 695-703

16. Michelsen BK, Petersen JS, Boel E, Moldrup A, Dyrberg T, Madsen OD (1991) Cloning, characterization and autoimmune recognition of rat islet glutamic acid decarboxylase in insulindependent diabetes mellitus. Proc Natl Acac Sci 88: 8754-8758

17. Christgau S, Schierbeck H, Aanstoot H-J et al. (1991) Pancreatic $\beta$ cells express two autoantigenic forms of glutamic acid decarboxylase, a 64-kDa hydrophilic form and a 64-kDa amphiphilic form which can be both membrane bound and soluble. J Biol Chem 266:21257-21264

18. Christie MR, Daneman D, Champagne P, Delovitch TL (1990) Persistence of antibodies to $64000-\mathrm{M}_{\mathrm{r}}$ islet cell protein after onset of Type 1 diabetes. Diabetes 39: 653-656

19. Brundstedt J, Nielsen JH, Lernmark $\AA$, Hagedorn Study Group (1984) Isolation of islets from mice and rats. In: Larner J, Pohl S (eds) Methods in diabetes research. Vol I. Laboratory methods, part C. John Wiley and Sons, New York, pp 245-258

20. Gornall AC, Bardawill CJ, David MM (1949) Determination of serum proteins by means of the Biuret Reaction. J Biol Chem 177:751-756

21. Chang YC, Gottlieb DI (1988) Characterization of the proteins purified with monoclonal antibodies to glutamic acid decarboxylase. J Neurochem 8:2123-2130

22. Karlsen AK, Hagopian WA, Grubin CE et al. (1991) Cloning and primary structure of a human islet isoform of glutamic acid decarboxylase from chromosome 10. Proc Natl Acad Sci 88: 83378341

23. Roberts E, Kuriyama K (1968) Biochemical-physiological correlations in studies of the gamma amino butyric acid system. Brain Res 8: 1-35

24. Reetz A, Solimena M, Matteoli M, Folli F, Takei K, de Camilli P (1991) GABA and pancreatic $\beta$-cells: colocalization of glutamic acid decarboxylase (GAD) and GABA with synaptic-like microvesicles suggests their role in GABA storage and secretion. EMBO J 10: 1275-1284

25. Robbins MS, Grouse LH, Sorenson RL, Elde RP (1981) Effect of muscimol on glucose-stimulated somatostatin and insulin release from the isolated, perfused rat pancreas. Diabetes 30: 168171

Received: 2 September 1991

and in revised form: 2 December 1991

Dr. M.R. Christie

Nuffield Department of Clinical Biochemistry

John Radcliffe Hospital

Headington

Oxford OX3 9DU

UK 